\title{
Cultural Responses to the Dust Bowl
}

\author{
Robert Alexander BA, Connie Nugent MLS
}

The Dust Bowl was an ecological disaster that brought misery and misfortune to the Great Plains region of the United States and Canada between 1930 and 1940. Coupled with the financial ruin of the Great Depression, the Dust Bowl was responsible for numerous health issues, deaths, and unprecedented migration away from the region. ${ }^{1}$

A multitude of dust storms ravaged the Great Plains, concentrating on the roughly bowl-shaped geographic area of southeastern Colorado, southwestern Kansas, the Oklahoma and Texas panhandles, and northeastern New Mexico. The phrase "Dust Bowl" was likely coined by journalist Robert Geiger in his reporting for the Associated Press on the massive Black Sunday storm of April 14, $1935 .^{2}$ According to historian Donald Wooster, some people liked the coined name Dust Bowl "as a satire on college football-first the Rose Bowl then the Orange Bowl, now the Dust Bowl-or they thought it described nicely what happened to the sugar bowl on the table." ${ }^{3} \mathrm{~A}$ number of agricultural, climatological, and socioeconomic factors converged at exactly the right point in history to create the conditions in which these storms flourished (Figure 1).

While statistics might report the facts regarding the effects on health during the Dust Bowl-Public Health records indicate an increase in respiratory diseases ${ }^{4}$-the human experience is lost. True, the physical and psychological effects of a natural disaster of this magnitude are documented in nonfiction accounts, but the human experience can be best revealed in literature and the arts. Short stories, novels, music, and film reflect the social history of the day that is not available in routine medical reports.

DOI: $10.12746 /$ swrccc.v6i22.433

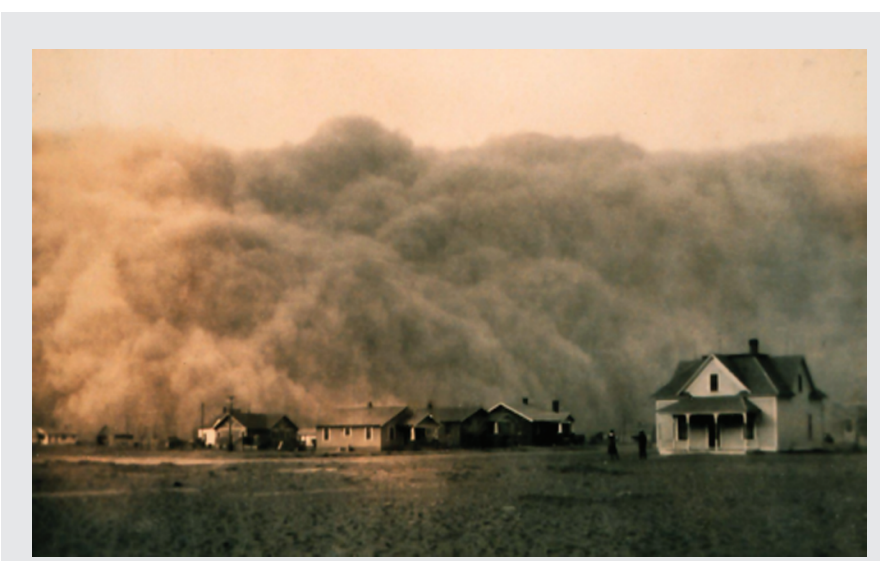

Figure 1. Dust storm approaching Stratford, Texas; Dust Bowl surveying in Texas. April 18, 1935 theb1365, NOAA's National Weather Service (NWS) Collection; NOAA George E. Marsh Album.

\section{The Dust Bowl in Literature}

Writers of fiction traditionally fashion their stories using characters, plots that involve the characters in some type of conflict, and settings that can influence the characters as they interact with the environment. The classic Dust Bowl novel by John Steinbeck, The Grapes of Wrath (1939), for example, is plot driven, portraying the Joad family as they emigrate from the Dust Bowl to the "promised land" of California. Unable to hold on to their Oklahoma land during the Depression, the family endures hardships on the journey ranging from abject poverty to overt prejudice toward "Okies" to exploitation by large agricultural corporations. ${ }^{5}$

Also written in 1939 but not published until 2004, Sanora Babb's novel Whose Names are Unknown presents a first-hand experience of hardscrabble farmers and their families as they struggle with "wind, wind, wind, and the mistake [that] resulted in dust, which covered fields and buildings, killed people and animals, and drove farmers out with nothing." 6 In one chapter, Julia keeps a diary of the weather conditions 
in April; most of her entries describe living with pervasive dust, and even on calm days, "everyone [is] spoiling the happiness of a clear day by digging dust."7 The dust ultimately takes its toll: driving home during a black dust storm, Mr. Starwood is trapped in his truck and is not found until the next day. "He wrote his will on a paper sack... He was revived but there is not much chance for him," ${ }^{8}$ and he soon dies, presumably from dust inhalation. These families, too, join the migration to California.

In other Dust Bowl literature, the setting itself becomes a character and drives the conflict. In Sinclair Ross's short story The Lamp at Noon, continuous wind and dust isolate Paul and Ellen on a farm parched by drought. The dust as character drives the couple apart-Paul is stoic, wanting to remain on the land, "... the struggle had given sternness, an impassive courage..." while Ellen harbors "... a nervous dread of what was still to come." She fears for the health of her baby, and would rock him, "...but a fear had obsessed her that in the dust-filled air he might contract pneumonia." ${ }^{10}$ Prophetic thoughts: at the end of the story, Paul finds Ellen outside in the dust-filled air with the dead baby clutched in her arms, "...the smother of dust upon his throat and lungs." 11 Paul realizes his impotence-

"Suddenly he merged from his numbness; suddenly the fields before him struck his eyes to comprehension. They lay black, naked.

Beaten and mounded smooth with dust as if a sea in gentle swell had turned to stone."12

In Karen Hesse's novel in verse Out of the Dust, a young girl in Oklahoma in 1934 listens to a teacher explain just how the Dust Bowl came to be, calling it "The Path of our Sorrow." In logical cause and effect, Miss Freeland delineates the sequence: The Great War required more wheat, so the farmers leased more land, bought bigger tractors, went into debt to grow wheat. After the war, wheat prices dropped, so farmers put cattle and sheep on the land. Grazing reduced the foliage to rubble, farmers plowed more land for more wheat, the water that had collected under the grass dried up, and

"Without the sod, the water vanished/ the soil turned to dust.
Until the wind took it, / lifting it up and carrying it away.

Such a sorrow doesn't come suddenly,

There are a thousand steps to take/ before you get there."

But now, /sorrow climbs up our front steps, Big as Texas, and we didn't even see it coming, Even though it'd been making its way straight for us all along. ${ }^{13}$

\section{The Dust Bowl in ARt}

While stories allow the reader to imagine what it must have been like to live during the Dust Bowl, paintings can represent to the viewer the conditions during the Dust Bowl. Unlike Grant Wood or Thomas Hart Benton, whose paintings of the Midwest and Great Plains present lush verdant landscapes that glorify agriculture, Alexandre Hogue depicted the harsh realities of the Dust Bowl resulting from land mismanagement (see Medicine in Art article in this issue of the Chronicles). An artist can suggest an attitude toward a subject using symbolism and composition, but photographs bring the viewer directly into the experience. As part of the New Deal, the Works Progress Administration (WPA) sent photographers across the United States to record the effects of the Depression. Many focused on the circumstances in the Dust Bowl states. Iconic photographs by Dorothea Lange evoke emotional responses of hopelessness against insurmountable odds. How does one survive the "perfect storm" of the Depression and the Dust Bowl? (Figure 2).

\section{The Dust Bowl in Music}

Woody Guthrie lived in the Texas panhandle during 1935, one of the worst years for dust. He wrote several songs describing life in the Dust Bowl, including "Dust Bowl Blues," which includes the lament, "when you got that dust pneumony, boy, it's time to go." 14 Unable to support his family, he joined the thousands of others migrating to California, as he hitchhiked, walked, and rode freight trains. ${ }^{15}$ Conditions in migrant camps were appalling, and Guthrie wrote 


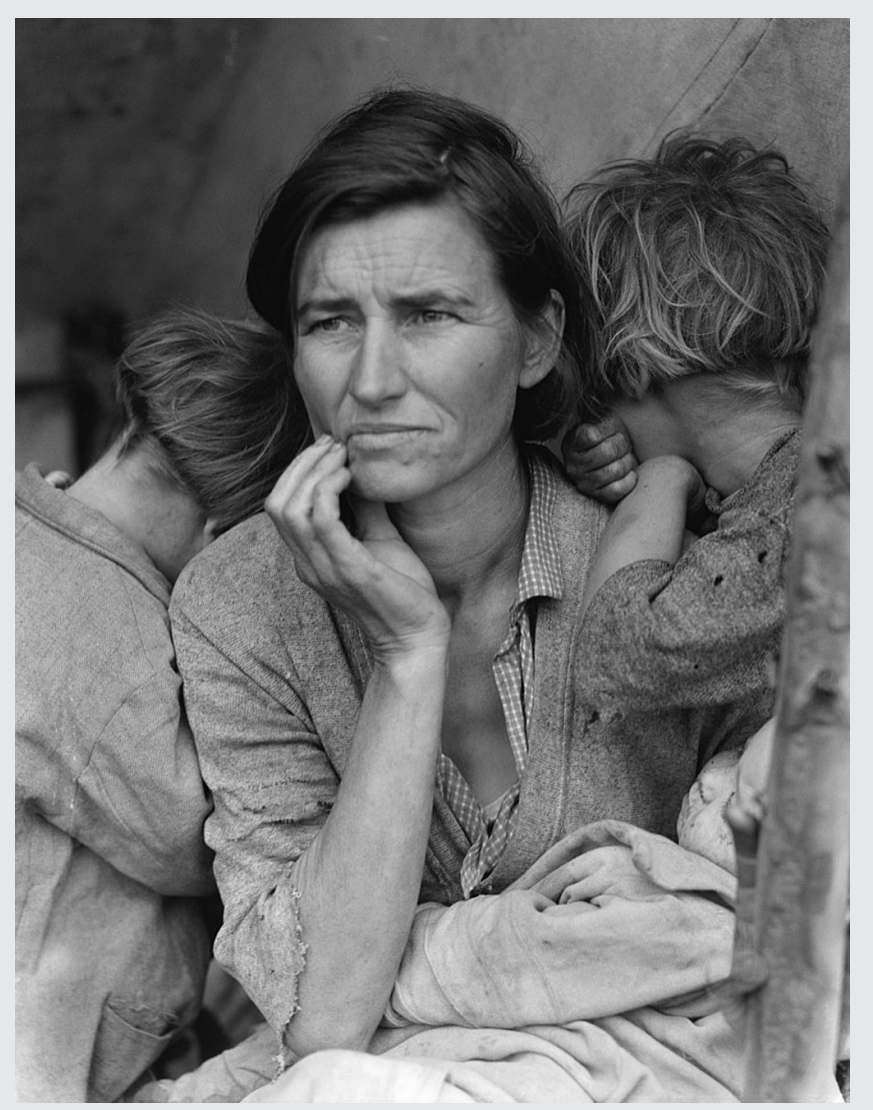

Figure 2. Dorothea Lange: "Migrant Mother" Library of Congress Prints and Photographs Division; digital ID fsa.8b29516. In 1936, Lange took this picture of Florence Thompson, a Dust Bowl migrant. The child on the right, Katharine, as an adult in 2008 issued a warning. See: Leonard, Tom. Woman whose plight defined Great Depression warns tragedy will happen again. http://www.telegraph.co.uk/news/ worldnews/northamerica/usa/3551264/Woman-whoseplight-defined-Great-Depression-warns-tragedy-willhappen-again.html

several songs in social protest. ${ }^{16}$ In the 1940 s, famed dancer and choreographer Sophie Maslow incorporated Guthrie's "Dust Bowl Ballads" into the soundtrack for her modern dance movements called Folksay, which emphasized the rhythms of authentic American rural life. ${ }^{17}$

\section{The Dust Bowl IN FILM}

Of course, the most memorable film on this subject is John Ford's The Grapes of Wrath (1940), based on Steinbeck's novel. As Tom Joad, Henry Fonda vows to fight for fair play for the downtrodden, promising, "I'll be there" wherever there's injustice. ${ }^{18}$ An early documentary, The Plow that Broke the Plains, written and directed by Pare Lorenz in 1936, provides raw footage of current weather events in the Dust Bowl showing the effects of agricultural land mismanagement. ${ }^{19}$ Lorenz also wrote and directed the short documentary The River in 1938 to illustrate the effects of topsoil runoff into the Mississippi River. ${ }^{20}$ Perhaps the most important documentary on the Dust Bowl is Ken Burns's comprehensive four episode miniseries that aired on the Public Broadcasting System in 2012. It chronicles "the worst man-made ecological disaster in American history" and includes interviews with the survivors, photographs of the devastation, and movie footage. PBS calls Dust Bowl "a morality tale about the relationship to the land that sustains us-a lesson we ignore at our peril." 21

\section{Conclusion}

According to anthropologist Cristina De Rossi, PhD, of London's Barnet and Southgate College, the word "culture" derives from the Latin colere, which means "to tend to the earth and grow, or cultivation and nurture." She suggests that "culture" relates to other words which "actively foster growth."22 During the years preceding the Dust Bowl, land mismanagement contributed to massive erosion, resulting in serious health and financial issues, which in turn impelled mass migration from the rural areas in the Great Plains. Writers, painters, and photographers recorded these events in efforts to understand the causes of the Dust Bowl, to recognize the effects on human and animal life, and to emphasize the need for solutions.

In turn, the US government created agencies and programs specifically to remedy drought and erosion problems in the Great Plains. These projects and organizations served the dual purpose of addressing the ecological and health issues created 
by the Dust Bowl as well as providing work for those whose livelihoods were affected by the storms. Over two million trees were planted in "shelterbelts" to provide windbreaks and to hold the topsoil; farmers were educated about and encouraged to rotate crops and to adopt other land conservation practices. Financial assistance was given in the form of government subsidies and improved banking practices. ${ }^{23}$ Literature and the arts worked in tandem to describe the human experience under physical and emotional duress and to stimulate an awareness of the need for a culture of sustained growth in tending and nurturing the earth.

Keywords: Dust Bowl; dust pneumonia; Dust Bowl migrants; John Steinbeck; Grapes of Wrath; Sanora Babb; Whose Names are Unknown; Woody Guthrie; Dorothea Lange

Submitted: $12 / 31 / 2017$

Accepted: $1 / 2 / 2018$

From: Department of Internal Medicine, Texas Tech University Health Sciences Center, Lubbock, TX

Reviewers: Gilbert Berdine MD, Leighann Jenkins MD Conflicts of interest: none

\section{REFERENCES}

1. McLeman RA, Dupre J, Ford LB, Ford J, Gajewski K, Marchildon $\mathrm{G}$. What we learned from the dust bowl: lessons in science, policy, and adaptation. Popul Environ 2014; 35:418.

2. Lee JA, Gill TE. Multiple causes of wind erosion in the dust bowl. Aeolian Research 2015;19:16.
3. Wooster, Donald. Quoted in Eschner, Kat. This 1000-mile long storm showed the horror of life in the Dust Bowl. https:// www.smithsonianmag.com/smart-news/1000-mile-longstorm-showed-horror-life-dust-bowl-180962847/ Accessed $12 / 29 / 2017$.

4. Brown EG, Gottlieb S, and Laybourn RL. Dust storms and their possible effect on health. Public Health Reports 1935; 50:1380-81.

5. Steinbeck, John. The Grapes of Wrath. Viking Press, 1939.

6. Babb, Sanora. Whose Names are Unknown. Norman, OK: University of Oklahoma Press, 2004. p. xiii.

7. Babb. p. 90.

8. Babb. p. 95.

9. Ross, Sinclair. The Lamp at Noon and Other Stories. Toronto: McClelland \& Mitchell Ltd., 2010. p. 4.

10. Ross. p. 2.

11. Ross. p.13.

12. Ross. p. 12.

13. Hesse, Karen. Out of the Dust. New York: Scholastic, 1997. p. 84.

14. http://woodyguthrie.org/Lyrics/Dust_Bowl_Blues.htm Accessed 12/29/2017. Note: You can listen to this song on YouTube as the background for a video of a family's. Dust Bowl experience: https://www.youtube.com/watch?v=jQYKJaWuj0Y.

15. http://woodyguthrie.org/biography/biography2.htm Accessed 12/29/2017.

16. http://woodyguthrie.org/biography/biography3.htm Accessed $12 / 29 / 2017$.

17. http://woodyguthrie.org/sophiemaslow.htm Accessed 12/29/2017.

18. http://www.imdb.com/title/tt0032551/?ref_=nv_sr_1 Accessed 12/30/2017.

19. http://www.imdb.com/title/tt0122662/ Accessed 12/29/2017.

20. http://www.imdb.com/title/tt0029490/?ref_=fn_al_tt_5 Accessed 12/29/2017.

21. http://www.pbs.org/kenburns/dustbowl/

22. https://www.livescience.com/21478-what-is-culture-definitionof-culture.html

23. McLeman. p. 428-9. 